\title{
CONCEPTUAL APPROACH FOR DETERMINING VARIABLES RELATED TO PERFORMANCE MEASUREMENT FOR RESEARCH A Literature Review
}

\author{
Muhammad TresnadiHikmat $^{\mathrm{a}}$ \\ Ina Primiana ${ }^{\mathrm{b}}$ \\ ${ }^{a}$ Universitas Padjadjaran, Jl Dipati Ukur No.46 Bandung 40132, Indonesia \\ ${ }^{b}$ Universitas Padjadjaran, Jl Dipati Ukur No.46 Bandung 40132, Indonesia \\ mtresnadihikmat@gmail.com
}

\begin{abstract}
Implementation of Performance Measurement System (PMS) has been challenging for researchers in the academic fields. And researchers find it important to know the possible variables to be studied in relation to performance measurement.
\end{abstract}

This paper has a purpose to discuss the theoretical backgrounds and current research in the field of performance measurement affecting firm performance to identify possibly related variables which will later can be used for further research.

The methodology used in this study is conducting literature study on the subject of performance measurement or performance management for the last 4 years, and conducting a systematic literature review of the papers to discover what affecting variables that are related to PMS and firm performance.

The findings are there are papers that in the last 4 years there are numerous papers discussing each variable that are affecting performance measurement implementation such as leadership involvement and organization culture. There are also independent variables affecting firm performance with the absence or no indication of a performance management system such as knowledge management, human resource management. The paper concluded that the most discovered variables are management information system, PMS frameworks, organizational and leadership.

Limitations of this study are that the study is based on accessible journals by the writer and each study has their own limitations respectively such as the amount of unit analysis which will further limit generalization.

This study will give contribution to the field of performance measurement system and management and can give guidelines and ground theory to researchers regarding the possible correlating variables that are eligible for further study.

Keywords: performance measurement systems (PMS), firm performance,literature review, variables affecting PMS

\section{INTRODUCTION}

Performance measurement study has evolved and always became a crucial subject of research because of the indepthaffectson how management generate organizational results which can be financial and non-financial. Measuring the performance of a company is an essential step for increasing the performance of the company as an effort of performance management.
The steps of performance management consist of many steps which all must be aligned with the basic vision, mission and strategy of the company. The components of a complete performance management system also plays an important role such as the existence of adequate performance variable perspectives, the existence of a dashboard system to easily identify what is the leading performance variable or the lagging variable. All these performance variables are translated or called as Key Performance Indicators (KPI).

There are plenty of study addressing the implementation of performance management systems such as the role of PMS as a managerial instrument for public research centers (Agostino et al.,2012). There are also study of PMS implemented in the manufacturing sector (Lin et al., 2014) and the banking sector (Munir et al., 2013). Another is the assessment of similarities and potential synergies between riskmanagementsystem (RMS) and PMS and possible avenues for future research (Arena et al,2014).

The implementation and development of an PMS model for business schools using an exploratory approach (Azis et al, 2014), is an example of how in-depth the study in performance management and measurement can go. This study signifies that different fields of industry should have an accurate perspectives and performance variables to be measured.

Factors affecting a success of implementing performance management has also been an interesting study for researchers. Some literature emphisize that leadership has an important role, others say the existence of a knowledge management system. Examples of these studies are such as one that studies that performance management system (PMS) can be the key factor determining whether an organization can manage its human resources effectively (Singh \&Twalo, 2015).

Although plenty of study studies on the implementation, there are few that study and list a complete comprehensive implicating factors, or factors that contribute successful implementation of a performance management system, specificallytallying the amount of variables that are encountered each.

Therefore should these variables be identified then it would give clues for researchers to develop a relationship model for the variables that is thought to have relationships between each other as a theoretical construct. And the developed 
construct could contribute to knowledge body of performance measurement and management.

\section{LITERATURE REVIEW}

There are plenty of studies that are discussing performance measurement and performance management in research. Performance management is a practice that consists of four phases which are design, implementation, use and review (Bourne et al.,2000).

Performance management is a means of getting better results from the organization, teams and individuals within an agreed framework of planned goals, objectives and standards (Armstrong and Murlis,1994) So according to that there are 3 areas of application which are : individual performance, team performance and corporate performance. Another definition of performance management is that is a range of practices that an organization engages in to enhance the performance of a target person or group with the ultimate purpose of improving organizational performance (DeNisi, 2000)

There are known approaches of performance management which are also called frameworks. A known framework is the process of balancing the performance management perspectives which are traditionally financial to nonfinancial perspectives which are known as Balancing the Scorecard (Kaplan and Norton,1996).

The indicating variables here are for a performance management system which scope is individual, team or corporate application. For corporate performance management framework, the application of performance management frameworks a as guide to conduct planning, execution and monitoring of the system is very crucial. The right choice of framework could be the meaning of a successfulness or unsuccessfulness of implementation.

Neely (2000) studied that performance management perspectives must consider stakeholder's satisfaction while other studies mentioned that performance management perspectives to be measured are not just financial but must be balanced with non-financial perspectives such as customer, internal process and learning and growth (Kaplan et.al 1992,1996, 2001).

Several known frameworks of performance management systems according the timeline of its discovery are :Performance Measurement Matrix (Keegan et al,.1989), The performance measurement questionnaire (Dixon et al,1990), The SMART performance pyramid (Lynch and Cross, 1991), Performance for World Class Manufacturing (Maskell, 1991), Quantum Performance Measurement Model (Hronec, 1993), The Balance Scorecard (Kaplan and Norton,1996), Performance Prism (Neely and Adams, 2000), Integrated Performance management system (Wibisono and Khan, 2002), Six Sigma Business Scorecard (Gupta, 2004)

\section{Methodology}

The method is conducting systematic literature review(SLR), finding the related variables using keywords and justified. Finding empiricalresearch that arestudying correlation of variables with performance measurement or with firm performance.

Literature review of this methodology can be found on studies similar to the other studies conducted such as by Choong (2013) in which conducted systematic approach in reviewing and examining existing PMS and Non-PMS Articles focus on features of measurement.

To conduct thorough investigation for this paper, the use of the SLR are conducting accordingly to steps such as : scoping study, definition of search protocol, application of exclusion criteria, data extraction, analysis and dissemination (Tranfield et al.,2003)

The steps of the review is based on observation to journals that are indexed in Proquest, and GoogleScholar where the keyword that is inputted to the search form are : "performance management", "performance management system", "performance measurement" and "performance measurement system".

The results are then viewed by the findings of each paper which narrows down to the main variables affecting the successfulness of performance management implementation.

\section{FINDINGS AND DISCUSSION}

After conducting the systematic literature review and thoroughly analyzing the variables that are related to performance measurement and management towards 58 papers selected papers surrounding the issue of Performance Management or Performance Measurement we could analyze the results as follow.

The variables are then listed accordingly as to Table 1 List of Papers with the Indicators relating to Performance Measurement, in the last section of this paper. After that is conducting a similarity analysis of possible similar factors that will function as a higher group level of variable. Then the higher level grouping are thentallied to calculate the amount of papers identified.

The findings of this paper are that variables that can be further studied can be summarized and shown in Table 1 List of Papers with the Indicators relating to Performance Measurement.The above mentioned and collected journals are then tabulated to see what factors that are contributing to the study and we then we create a graph on the findings. 


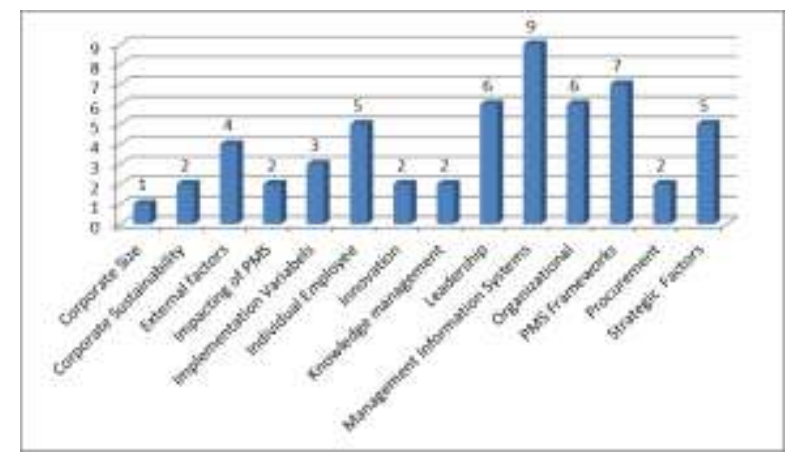

Fig 1. The effecting variables for performance management and measurement

After we have identified these variables that can be further studied, we could then have several combination of constructs towards the main variables Performance Management and Measurement System (PMS).

Although the literature study gives a glimpse of what can be further studied, there are other variables that can be discovered beyond this which affects the PMS as the main variable. Such variable can be a more sharpened grouping such as employee engagement, competency of PMS staff, the organizational structure or others.

\section{Conclusions}

Conclusion of this paper is that after conducting a literature review in the field of performance management and measurement, we could find several factors that are affecting the PMS as main variable where some of these variables can be obviously justifiable.

The top variables discovered here are : management information system, PMS frameworks, organizational and leadership. This analysis concludes that these variables have very important roles to the success of performance management system.

Limitations of this study are that the study is based on accessible journals by the writer which areProquest and Google Scholar. Further study will give more impact should it be analyzed among verified peer reviewed journals and filtered only for example Scopus indexed journals. The amount of unit analysis which will further limit generalization.

This study will give contribution to the field of performance measurement system and management and can give guidelines and ground theory to researchers regarding the possible correlating variables that are eligible for further study. For researchers in Performance Management and measurement, this study will validate their hypothetical assumptions of variables that they are currently studying.

\section{REFERENCES}

Abdali, S., Hourani, M. a., Abuerrub, A., \&Shambour, Q. (2013).Toward a Conceptual Framework for Integrating Enterprises Performance and Risk Management.Journal of Management Research, 5(4), 145-166.

Arena, M., \&Arnaboldi, M. (2014). Risk and performance management: are they easy partners? Management Research Review, 37(2), 152-166. doi: http://dx.doi.org/10.1108/MRR-08-20120180

Armstrong, M and Murlis,H(1994), Reward Management, Kogan Page , London

Ates, A., Garengo, P., Cocca, P., \&Bititci, U. (2013).The development of SME managerial practice for effective performance management.Journal of Small Business and Enterprise Development, 20(1), 28-54. doi: http://dx.doi.org/10.1108/14626001311298402

Atkinson, M. (2012). Developing and using a performance management framework: a case study. Measuring Business Excellence, 16(3), 4756.doi:

http://dx.doi.org/10.1108/13683041211257402

Azis , A.M., Simatupang T.M., Wibisono,D.\&Basri, M.H (2014)Business School's Performance management system Standards Design,International Education Studies; Vol. 7, No. $3 ; 2014$,

Barnes, D., \& Hinton, C. M. (2012).Reconceptualising ebusiness performance measurement using an innovation adoption framework.International Journal of Productivity and Performance Management, 61(5), 502-517. doi: http://dx.doi.org/10.1108/17410401211232948

Bernadette Nambi, K., \& Werner, A. (2013).Challenges impacting performance management implementation in public universities.African Journal of Economic and Management Studies, 4(2), 223-243.

Bezdrob, M., \& Car, M. B. (2012, Jun 13-16Jun 13-16, 2012). Performance Measurement Model Developing And Testing A Measurement Model Based On The Simplified Balanced Scorecard Method, Zagreb.

Bianca, A. C. G., Mirthe van de, B., \& Celeste, P. M. W. (2012).Enabling performance measurement in a small professional service firm.International Journal of Productivity and Performance Management, 61(8), 839-862. doi: http://dx.doi.org/10.1108/17410401211277110 
Biriescu, S. (2013).Regionalization, Performance Management and Software Technology.Revista de Management Comparat International, 14(4), 596-607.

Blasini, J., \&Leist, S. (2013). Success factors in process performance management. Business Process Management Journal, 19(3), 477-495. doi: http://dx.doi.org/10.1108/14637151311319914

Budimir, V. P., Raguz, M. J. P., \&Zupan, M. B. (2012, 2012 Jun 13-16, 2012). Development Of The Balanced Scorecard Performance Management For Public Sector And Budgetary Users In Croatia, Zagreb.

Chan, F. T. S., Nayak, A., Raj, R., Chong, A. Y.-L., \&Manoj, T. (2014). An innovative supply chain performance measurement system incorporating Research and Development (R\&amp;D) and marketing policy. Computers \& Industrial Engineering, 69(0), 64-70. doi: http://dx.doi.org/10.1016/j.cie.2013.12.015

Choong,K.K.(2013) Understanding the features of performance measurement system: a literature review Measuring Business ExcellenceVol 17 No.4 2013, pp 102-121

Conaty, F. J. (2012). Performance management challenges in hybrid NPO/public sector settings: an Irish case. International Journal of Productivity and Performance Management, 61(3), 290-309. doi: http://dx.doi.org/10.1108/17410401211205650

de Waal, A., \&Kourtit, K. (2013). Performance measurement and management in practice.International Journal of Productivity and Performance Management, 62(5), 446-473.

Dechow, N. (2012). The balanced scorecard: subjects, concept and objects - a commentary. Journal of Accounting \& Organizational Change, 8(4), 511-527. doi: http://dx.doi.org/10.1108/18325911211273509

Decramer, A., Smolders, C., Vanderstraeten, A., Christiaens, J., \&Desmidt, S. (2012). External pressures affecting the adoption of employee performance management in higher education institutions.Personnel Review, 41(6), 686-704. doi: 10.1111/j.1467-6486.1993.tb00302.x

Deepa, R. (2012). Impact of Performance management system on HR Outcomes.Review of HRM, 1, 4357. doi: 10.1002/hrm.20032 10.1186/14784491-4-2

DeNisi, A S and Kluger,A.N(2000) Feedback effectiveness:can 350 degree appraisals be improved ? Academy of Management Executive,14(1),pp 129-39
Demeter, C., \&Tapardel, A.-C.P. (2013). Public And Private Leadership And Performance Management. Manager(17), 162-167.

Dixon, J.R., Nanni, A.J., \&Vollmann, T.E. (1990).The New Performance Challenge - Measuring Operations for World-class Competition.Dow Jones-Irwin, Homewood, IL.

Egbeleke, A. A. (2014). Strategic Corporate Responsibility and Sustainability Performance Management Model.Journal of Management and Sustainability, 4(2), 92-105.

Franceschini, F., Galetto, M., \&Turina, E. (2013).Techniques for impact evaluation of performance measurement systems.The International Journal of Quality \& Reliability Management, 30(2), 197-220. doi: http://dx.doi.org/10.1108/02656711311293599

Gadenne, D., Lokman, M., Sands, J., Winata, L., \&Hooi, G. (2012). The influence of sustainability performance management practices on organisational sustainability performance. Journal of Accounting \& Organizational Change, 8(2), 210-235. doi: http://dx.doi.org/10.1108/18325911211230380

Gibson, E. (2013). Perceived Obstacles As The Indicators Of Adaptive Paths To Performance Management: Tracing Exploration And Exploitation In Surveys Of Public Managers. International Journal of Organization Theory and Behavior, 16(3), 285-323.

Goh, S. C. (2012). Making performance measurement systems more effective in public sector organizations.Measuring Business Excellence, 16(1), 31-42.doi: http://dx.doi.org/10.1108/13683041211204653

Gupta, V., \& Kumar, S. (2013). Impact of performance appraisal justice on employee engagement: a study of Indian professionals. Employee Relations, 35(1), 61-78. doi: http://dx.doi.org/10.1108/01425451311279410

Gupta , Praveen (2004), The Six Sigma Business Scorecard, McGraw Hill, Second Edition

Hawke, L. (2012). Australian public sector performance management: success or stagnation? International Journal of Productivity and Performance Management, 61(3), 310-328. doi: http://dx.doi.org/10.1108/17410401211205669

Hronec, S.M (1993), Vital Signs- Using Quality, Time and Cost performance measurement to chart your company's future

Huang, L., Zhou, L., \& Wang, B. (2014).Approaches to Achieve Personal Values in Performance 
Management of

Service

Government.International Journal of Business and Social Science, 5(6).

Jankulovic, A., \&Skoric, V. (2013).Performance management system implementation in a Southeast European transitional country. Journal for East European Management Studies, 18(2), 173-190.

Kaplan, R. S. (2012). The balanced scorecard: comments on balanced scorecard commentaries. Journal of Accounting \& Organizational Change, 8(4), 539-545.

doi: http://dx.doi.org/10.1108/18325911211273527

Kaplan, R.S. \& Norton, D.P. (1996).Using the balanced scorecard as a strategic management system. Harvard Business Review. January-February, 75-85.

Keegen, D.P.,Eiler,R.G.,andJones,C.R(1989) "Are your performance measures obsolete?",Management Accounting,70(12),pp.45-50

Lynch, R.L., \& Cross, K.F. (1991). Measure Up: Yardsticks for continuous improvement.Cambridge: Blackwell Publishers

Majumder, M., \&Arora, S. (2013).Rethinking Performance management system: A Feminist Critique.Review of HRM, 2, 6-13.

Mary Lee, R., Biondi, L., Gomes, R., Melo, A. I., Ohemeng, F., Perez-Lopez, G., . . .Sutiyono, W. (2012). Current state of public sector performance management in seven selected countries.International Journal of Productivity and Performance Management, 61(3), 235-271. doi:

http://dx.doi.org/10.1108/17410401211205632

Maskell, Brian H. (1991) Performance Measurement for World Class Manufacturing: A Model for American Companies, Productivity Press

Munir, R., Baird, K., \&Perera, S. (2013). Performance measurement system change in an emerging economy bank.Accounting, Auditing \& Accountability Journal, 26(2), 196-233.doi: 10.1016/j.aos.2006.09.007http://dx.doi.org/10.1 $108 / 09513571311303710$

Nankervis, A. R., Stanton, P., \& Foley, P. (2012).Exploring the Rhetoric and Reality of Performance management systems and Organisational Effectiveness - Evidence from Australia.Research \& Practice in Human Resource Management, 20(1), 1-24.

Neely, A., \& Adams, C. (2000) Perspectives on Performance: The Performance Prism. In
Bourne, M. (ed.). Handbook of Performance Measurement, London: Gee Publishing.

Nixon, P., Harrington, M., \& Parker, D. (2012). Leadership performance is significant to project success or failure: a critical analysis. International Journal of Productivity and Performance Management, 61(2), 204-216. doi: http://dx.doi.org/10.1108/17410401211194699

Nura, A. A., \& Osman, N. H. (2013). How do Procurement and Separation relate with Performance management system among Employees? Testing the Mediating role of ICT Adoption.Information Management and Business Review, 5(10), 492499.

Olufunso, O., \& Tony, O. A. (2014).Effect Of Strategic Performance Management On OrganisationalNichein A Challenging Economy. International Journal of Marketing and Technology, 4(4), 1-18.

Pedro Sena, F., Shamsuzzoha, A. H. M., Toscano, C., \& Cunha, P. (2012).Framework for performance measurement and management in a collaborative business environment. International Journal of Productivity and Performance Management, 61(6), 672-690. doi: http://dx.doi.org/10.1108/17410401211249210

Peignot, J., Peneranda, A., \&Amabile, S. (2013). Strategic Decision Support Systems for Local Government: A Performance Management Issue? The Use of Information Systems on the Decision-making and Performance Management of Local Government.International Business Research, 6(2), 92-100.

Peljhan, D., Kejzar, K. Z., \&Ponikvar, N. (2012). The Importance Of Performance Management Tools Usage For Surviving The Economic Crisis. The International Business \& Economics Research Journal (Online), 11(12), 1299-n/a.

Qureshi, A., \& Hassan, M. (2013). Impact of performance management on the organisational performance: An analytical investigation of the business model of McDonalds. International Journal of Academic Research in Economics and Management Sciences, 2(5), 54-76.

Savu, I. F., Ioane, V., Rãdulescu, M. R., \&Ceausu, I. (2012).A Performance Management Policy Model for Romanian Banks Employees.Revista de Management Comparat International, 13(3), 426-435.

Schläfke, M., Silvi, R., \&Möller, K. (2013).A framework for business analytics in performance management. International Journal of Productivity and Performance Management, 62(1), 110-122. doi: http://dx.doi.org/10.1108/17410401311285327 
Shahmehr, F. S., Safari, N., Jamshidi, M. J., \&Yaghoobi, N.M. (2014). The Impact of Performance Management on Mission Statement and Operational Goal Setting. International Journal of Business and Management, 9(11), 189-198.

Singh, A. (2012). Performance management system Design, Implementation and Outcomes in Indian Software Organizations: A Perspective of HR Managers. South Asian Journal of Management, 19(2), 99-120.

Skapa, R., \&Klapalová, A. (2012). Reverse logistics in Czech companies: increasing interest in performance measurement. Management Research Review, 35(8), 676-692. doi: http://dx.doi.org/10.1108/01409171211247686

Soudani, S. N. (2012). The Usefulness of an Accounting Information System for Effective Organizational Performance. International Journal of Economics and Finance, 4(5), 136-145.

Taticchi, P., Balachandran, K., \&Tonelli, F. (2012). Performance measurement and management systems: state of the art, guidelines for design and challenges. Measuring Business Excellence, $16(2)$,

41-54.doi: http://dx.doi.org/10.1108/13683041211230311

Tranfield,D.,Denyer,D.,Smart,.P(2003) Towards a Methodology for Developing Evidence Informed Management Knowledge by means of Systematic Review, British Journal of Management, 14,207-222

Wibisono, D., \& Khan, M. (2002a). A framework of performance measurement system design for manufacturing, Advances in Business Paradigms and Supporting Technologies. Proceedings of the 18th International Conference on CAD/CAM, Robotics and Factories of the Future, July 3-5, Porto, Portugal 
Tabel 1. List of Papers with the Indicators relating to Performance Measurement

\begin{tabular}{|c|c|c|c|}
\hline Affecting Variables & Group & Authors & Total \\
\hline Risk Management & Strategic Factors & $\begin{array}{l}\text { (Arena \& Arnaboldi, 2014), (Abdali, Hourani, Abuerrub, } \\
\text { \& Shambour, 2013) }\end{array}$ & 2 \\
\hline Strategic (long term) Planning & Strategic Factors & (Ates, Garengo, Cocca, \& Bititci, 2013) & 1 \\
\hline PMS Framework & PMS Frameworks & (Atkinson, 2012) & 1 \\
\hline Innovation & Innovation & (Barnes \& Hinton, 2012) & 1 \\
\hline formal performance management environment; & Implementation Variabels & (Bernadette Nambi \& Werner, 2013) & 1 \\
\hline employee engagement/communication problems; & Individual Employee & (Bernadette Nambi \& Werner, 2013) & 1 \\
\hline institutional governance challenges & Leadership & (Bernadette Nambi \& Werner, 2013) & 1 \\
\hline institutional systems & Management Information Systems & (Bernadette Nambi \& Werner, 2013) & 1 \\
\hline Design model of PMS & PMS Frameworks & (Bezdrob \& Car, 2012) & 1 \\
\hline Knowledge management & Knowledge management & (Bianca et al., 2012) & 1 \\
\hline Firm strategy & Strategic Factors & (Bianca, Mirthe van de, \& Celeste, 2012) & 1 \\
\hline information quality, process quality, system quality & Management Information Systems & (Blasini \& Leist, 2013) & 1 \\
\hline PMS Frameworks (BSC) & PMS Frameworks & (Budimir, Raguz, \& Zupan, 2012) & 1 \\
\hline innovation & Innovation & (Chan, Nayak, Raj, Chong, \& Manoj, 2014) & 1 \\
\hline power distribution; tensions across priority objectives & Leadership & $($ Conaty, 2012) & 1 \\
\hline culture and institutional clashes; & Organizational & (Conaty, 2012) & 1 \\
\hline Organizational Comitment & Organizational & (de Waal \& Kourtit, 2013) & 1 \\
\hline PMS Frameworks (BSC) & PMS Frameworks & (Dechow, 2012) & 1 \\
\hline External pressure & External factors & $\begin{array}{l}\text { (Decramer, Smolders, Vanderstraeten, Christiaens, \& } \\
\text { Desmidt, 2012) }\end{array}$ & 1 \\
\hline HR Outcomes & Impacting of PMS & (Deepa, 2012) & 1 \\
\hline Leadership & Leadership & (Demeter \& Tapardel, 2013) & 1 \\
\hline Strategic Corporate Responsibility & Strategic Factors & (Egbeleke, 2014) & 1 \\
\hline Impact of PMS & Impacting of PMS & (Franceschini, Galetto, \& Turina, 2013) & 1 \\
\hline Organizational sustainabity & Corporate Sustainability & (Gadenne, Lokman, Sands, Winata, \& Hooi, 2012) & 1 \\
\hline Percieved Obsticles & Implementation Variabels & (Gibson, 2013) & 1 \\
\hline a learning and evalua tive organiza tional culture & Knowledge management & (Goh, 2012) & 1 \\
\hline managerial discretion, & Leadership & (Goh, 2012) & 1 \\
\hline stakeholder involvement & Leadership & (Goh, 2012) & 1 \\
\hline Employee Engagement & Individual Employee & (Gupta \& Kumar, 2013) & 1 \\
\hline $\begin{array}{l}\text { strong external (political), structural and technical } \\
\text { factors }\end{array}$ & External factors & (Hawke, 2012) & 1 \\
\hline Personal Values & Individual Employee & (Huang, Zhou, \& Wang, 2014) & 1 \\
\hline In SMEs & Corporate Size & (Jankulovic \& Skoric, 2013) & 1 \\
\hline PMS Framework (BSC) & PMS Frameworks & (Kaplan, 2012) & 1 \\
\hline Feminism & Individual Employee & (Majumder \& Arora, 2013) & 1 \\
\hline Macroeconomic factors & External factors & (Mary Lee et al., 2012) & 1 \\
\hline Organizational Change & Organizational & (Munir, Baird, \& Perera, 2013) & 1 \\
\hline Organiztional effectiveness & Organizational & (Nankervis, Stanton, \& Foley, 2012) & 1 \\
\hline Leadership & Leadership & (Nixon, Ha rrington, \& Parker, 2012) & 1 \\
\hline Employee Separation & Individual Employee & (Nura \& Osman, 2013) & 1 \\
\hline Procurement & Procurement & (Nura \& Osman, 2013) & 1 \\
\hline Organizational Niche & Organizational & (Olufunso \& Tony, 2014) & 1 \\
\hline PMS Framework (BSC) & PMS Frameworks & (Pedro Sena et al., 2012) & 1 \\
\hline ICT Based Solution & Management Information Systems & (Pedro Sena, Shamsuzzoha, Toscano, \& Cunha, 2012) & 1 \\
\hline Decision Support System & Management Information Systems & (Peignot et al., 2013) & 1 \\
\hline Information Systems & Management Information Systems & $\begin{array}{l}\text { (Peignot, Peneranda, \& Amabile, 2013) (Nura \& Osman, } \\
\text { 2013)(Biriescu, 2013) }\end{array}$ & 3 \\
\hline Corporate survival & Corporate Sustainability & (Peljhan, Kejzar, \& Ponikvar, 2012) & 1 \\
\hline Organizational Performance & Organizational & (Qureshi \& Hassan, 2013) & 1 \\
\hline Policy Model & External factors & (Savu, Ioane, Rãdulescu, \& Ceausu, 2012) & 1 \\
\hline Business Analytics & Management Information Systems & (Schläfke, Silvi, \& Möller, 2013) & 1 \\
\hline Operational variabel & Implementation Variabels & (Shahmehr, Safari, Jamshidi, \& Yaghoobi, 2014 & 1 \\
\hline Mission Vision & Strategic Factors & (Shahmehr, Safari, Jamshidi, \& Yaghoobi, 2014) & 1 \\
\hline Design, implementation, outcome & PMS Frameworks & (Singh, 2012) & 1 \\
\hline Reverse logistics & Procurement & (Skapa \& Klapalová, 2012) & 1 \\
\hline Accounting Information System & Management Information Systems & (Soudani, 2012) & 1 \\
\hline Suitable framework & PMS Frameworks & (Taticchi, Balachandran, \& Tonelli, 2012) & 1 \\
\hline
\end{tabular}

